\title{
Diazotised Suhphanilic Acid Reagent for the Determination of Trace Amounts of Cephadroxil in Aqueous Solution - Application to Pharmaceutical Preparations
}

Nabeel Sabeh Othman

Department of Chemistry, College of Science. University of Mosul.
Received

12 / 09 / 2007
Accepted

05 / 11 / 2007

\section{الخلصـ a}

يشمل هذا البهث طوير طريقة طيفية بسيطة لقدير للسفادروكسل في المحلول

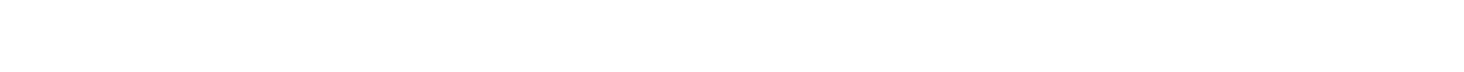
بوجود هيدروكسيد الصويوم، لتكوين صبغة آزوية ذات لون الصفر التي تكون ذائبة في الماء الماء

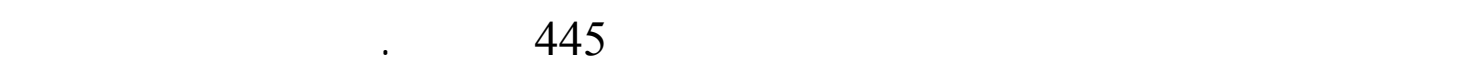

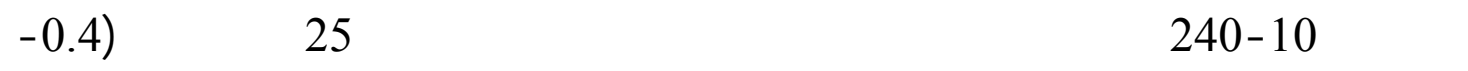

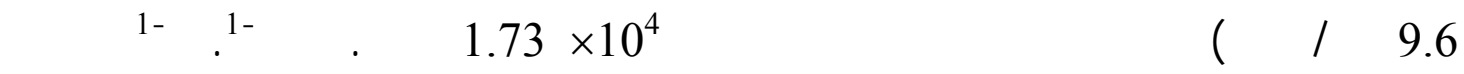

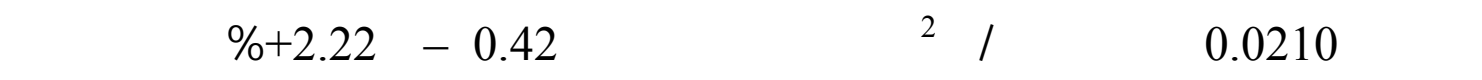

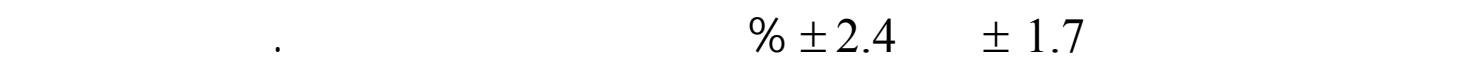

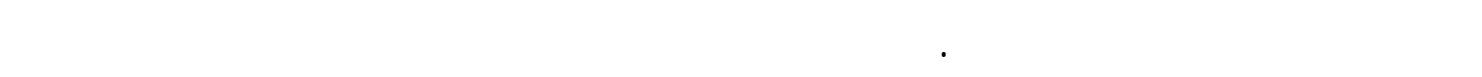
المستحضرات الصيدلانية المختلفة.

\section{ABSTRACT}

A simple spectrophotometric method for the determination of cephadroxil in aqueous solution is developed. The method is based on the coupling of cephadroxil with diazotised sulphanilic acid reagent in the presence of sodium hydroxide. The yellow azo-dye formed is watersoluble, stable, and shows maximum absorption at $445 \mathrm{~nm}$. Beer's law is obeyed over the range $10-240 \mu \mathrm{g} / 25 \mathrm{ml}(0.4-9.6 \mathrm{ppm})$ with a molar absorptivity of $1.73 \times 10^{4} 1 . \mathrm{mol}^{-1} \mathrm{~cm}^{-1}$, Sandell's sensitivity index of 0.0210 $\mu \mathrm{g} / \mathrm{cm}^{2}$, a relative error of -0.42 to $+2.22 \%$ and a relative standard 
deviation of \pm 1.7 to $\pm 2.4 \%$, depending on the concentration level. The composition of the yellow azo-dye has been evaluated. The proposed method has been successfully applied to the determination of cephadroxil in various pharmaceutical preparations.

\section{Introduction}

Cephadroxil is an antibiotic in a class of drugs called cephalosporins. Cephadroxil is used to treat many different types of bacterial infections such as bronchitis, tonsillitis, ear infections, skin infections, and urinary tract infections. Cephadroxil may also be used for purposes other than those cited[1].

A variety of techniques has been used for the determination of cephadroxil: chromatography [2,3], flow injection [4,5], and fluorometry $[6,7]$. Also, various spectrophotometric methods have been used in determination of cephadroxil as pure and in pharmaceuitical preparations using reagents such as diazotised benzocaine in the presence of triethylamine [8], diazotised $p$-nitroaniline [9], 4-aminoantipyrine in the presence of an alkaline oxidizing agent (hexacyanopherateIII) [10], 3-methyl-2benzothiazolinone hydrazone hydrochloride in the presence of ceric ammonium sulphate, 4-aminophenazone in the presence of potassium hexacyanopherrate (III), 2,6-dichloroquinone-4-chlorimide [11], $\mathrm{Cu}$ (II) and $\mathrm{V}(\mathrm{V})$ in sulphuric acid [12], Folin-Ciocalteu reagent in presence of sodium hydroxide and stannous chloride [13], molybdophosphoric acid as an oxidising agent [14], Ce (IV) or Fe (III) [15], after nitration a subsequent complexation with an nucleophilic reagent, nitrosation and subsequent metal chelation, coupling with diazo reagent, and reaction with copper and extraction of the resulting chelate into chloroform [16].

However some of above methods suffer from several disadvantage such as the need for non aqueous medium [8] or extraction of the resulting dye into non- aqueous solvent [16].

The objective of the investigation reported in this paper is to evaluate a simple spectrophotometric method for the determination of cephadroxil; the method is based on coupling with diazotised sulphanilic acid in basic medium. The resulting yellow dye formed proves to be intense, watersoluble and stable. 


\section{Materials and Methods}

\section{Apparatus}

The spectrophotometric measurements are carried out on Shimadzu UV-Visible Recording Spectrophotometric UV-160, using 1-cm silica cells.

\section{Reagents}

All chemicals used are of the highest purity available.

Cephadroxil working solution, $100 \mu \mathrm{g} / \mathrm{ml}$. A $0.01 \mathrm{~g}$ amount of cephadroxil is dissolved in distilled water with warming, then the volume is completed to $100 \mathrm{ml}$ in a volumetric flask, the solution is stable for one week at least.

Diazotised sulphanilic acid reagent solution, $50 \mathrm{mM}$. A $0.865 \mathrm{~g}$ of sulphanilic acid is dissolved in about $75 \mathrm{ml}$ of distilled water and the mixture is heated until the clear solution is obtained, then $1 \mathrm{ml}$ of concentrated hydrochloric acid is added, the mixture is then cooled to 0 $5^{\circ} \mathrm{C}$ in an ice- bath, and a $0.345 \mathrm{~g}$ sodium nitrite is added and stirred vigorously. After 5 minutes the solution is made up to volume in $100 \mathrm{ml}$ volumetric flask with cooled distilled water, and is kept in a brown bottle in a refrigerator .This solution is prepared freshly each day [17].

Sodium hydroxide solution, $1 N$. This solution is prepared by appropriate dilution of the concentrated volumetric (Fluka) solution with distilled water and then transferred to a plastic bottle.

\section{Solution of pharmaceutical preparations}

Cephadroxil tablets solution, $100 \mu \mathrm{g} . \mathrm{ml}^{-1}$. Weigh and finely powder 10 tablets (each one contains $500 \mathrm{mg}$ cephadroxil), an accurately weighed amount of powder equivalent to $0.01 \mathrm{~g}$ cephadroxil is dissolved in $50 \mathrm{ml}$ distilled water then the solution is warmed with shaking to increase the solubility, filtered into $100-\mathrm{ml}$ calibrated flask, then the solution is completed to the volume with a distilled water.

Cephadroxil capsule solution, $100 \mu \mathrm{g} \cdot \mathrm{ml}^{-1}$. Weigh and mix the contents of five capsules (each one contains $500 \mathrm{mg}$ cephadroxil), an accurately weighed amount of powder equivalent to $0.01 \mathrm{~g}$ cephadroxil is dissolved in $50 \mathrm{ml}$ distilled water then the solution is warmed with shaking to increase the solubility, filtered into $100-\mathrm{ml}$ calibrated flask, then the solution is completed to the volume with a distilled water.

Cephadroxil suspension solution, $100 \mu \mathrm{g} \cdot \mathrm{ml}^{-1}$. This solution is prepared by dissolving the content of the container in mixture containing $5 \mathrm{ml}$ of 
hydrochloric acid $(0.1 \mathrm{~N})$ and $10 \mathrm{ml}$ of ethanol then the solution is diluted to $60 \mathrm{ml}$ with distilled water (each $5 \mathrm{ml}$ contain $250 \mathrm{mg}$ cephadroxil), after filteration of the solution, $2 \mathrm{ml}$ which equivalent to $0.1 \mathrm{~g}$ cephadroxil is transferred in to a $100-\mathrm{ml}$ calibrated flask and the volume is completed with a distilled water.A $10 \mathrm{ml}$ of the above solution is diluted to $100 \mathrm{ml}$ to prepare $100 \mu \mathrm{g} \mathrm{ml}^{-1}$ solution.

Procedure and Calibration graph. To a series of $25-\mathrm{ml}$ volumetric flasks transfere $10-280 \mu \mathrm{g}(0.4-11.2 \mathrm{ppm})$ of cephadroxil, $4 \mathrm{ml}$ of diazotised sulphanilic acid $(50 \mathrm{mM})$ and $6 \mathrm{ml}$ of $1 \mathrm{~N} \mathrm{NaOH}$ and the volumes are made to the mark with distilled water. The absorbances are read against a reagent blank, prepared in the same manner but without cephadroxil, at $445 \mathrm{~nm}$ using $1-\mathrm{cm}$ cells. The calibration graph is linear over the range $10-240 \mu \mathrm{g} / 25 \mathrm{ml}(0.4-9.6 \mathrm{ppm})$ and higher concentrations show negative deviation (Fig.1). The molar absorptivity, calculated in the region of least photometric error and at the wavelength of maximum absorption, is found to be $1.73 \times 10^{4} 1 . \mathrm{mol}^{-1} . \mathrm{cm}^{-1}$, with Sandell sensitivity index of $0.021 \mu \mathrm{g} . \mathrm{cm}^{-2}$.

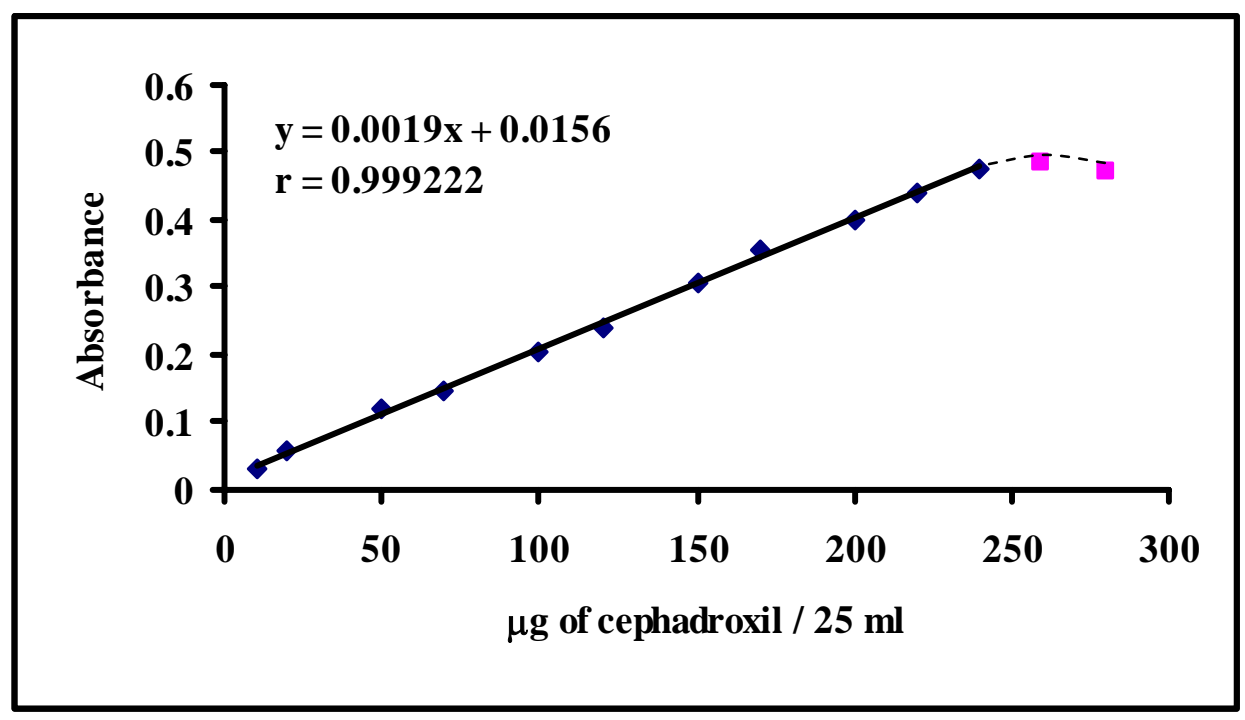

Fig. 1: Calibration graph of cephadroxil determination

\section{Results and Discussion}

For the subsequent experiments. $100 \mu \mathrm{g}$ of cephadroxil is taken and final volumes are brought to $25 \mathrm{ml}$ with distilled water.

Absorption spectra. When cephadroxil in aqueous solution is treated with diazotized sulphanilic acid reagent solution, an absorption peak is obtained showing intense absorption at $445-\mathrm{nm}$ characteristic of the yellow dye. The 445-nm wavelength of maximum absorption has been 
used in all subsequent experiments. The reagent blank shows very nill absorption (0.036) at the wavelength of maximum absorption (Fig.2).

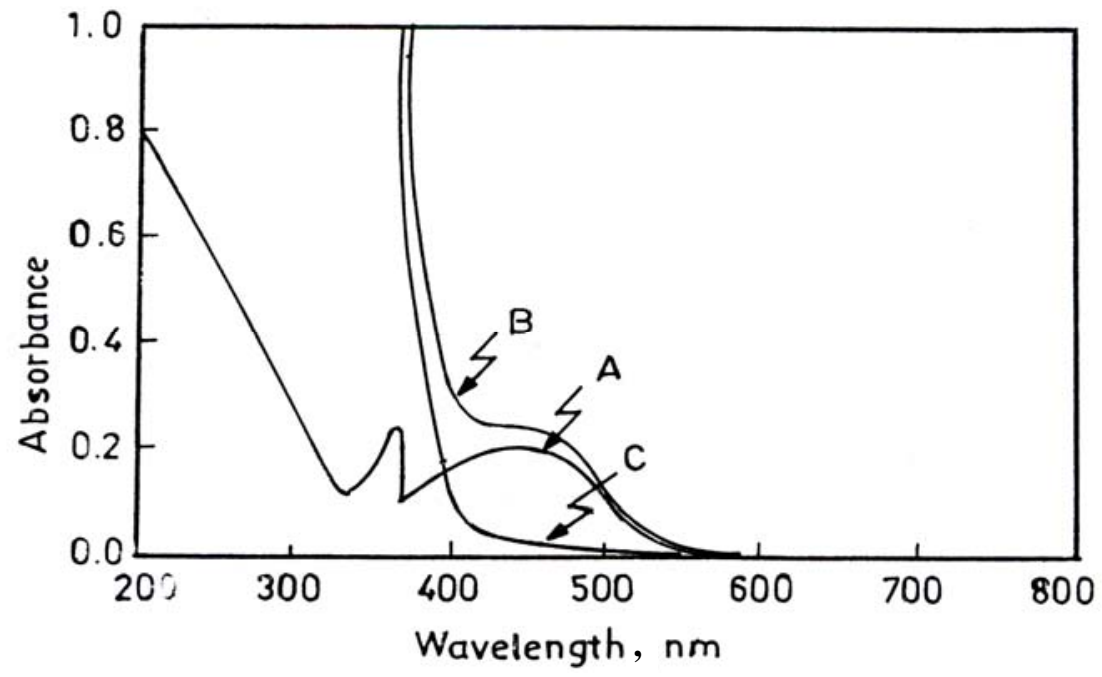

Fig. 2: Absorption spectra of $100 \mu \mathrm{g}$ cephadroxil / $25 \mathrm{ml}$ treated according to the recommended procedure and measured against

(A) reagent blank, (B) distilled water and (C) reagent blank measured against distilled water

Study of the optimum reaction conditions. The various parameters affecting and related to the yellow azo-dye have been studied and optimum conditions have been selected.

Effect of base. The preliminary experiments have shown that the azo-dye develops only completely in alkaline medium. Different amounts of bases (strong and weak) have been used (Table1).

Table 1: The effect of base on absorbance and colour contrast

\begin{tabular}{|c|c|c|c|c|c|c|c|}
\hline \multirow{2}{*}{$\begin{array}{l}\text { Base used } \\
\quad(1 \mathrm{~N}) \\
\text { Solution }\end{array}$} & \multirow{2}{*}{ Variable } & \multicolumn{5}{|c|}{ Absorbance* / $\mathrm{ml}$ of base used } & \multirow{2}{*}{ pH range } \\
\hline & & 1.0 & 1.5 & 2.0 & 2.5 & 3.0 & \\
\hline \multirow{2}{*}{$\mathrm{NaOH}$} & A & 0.153 & 0.162 & 0.112 & 0.102 & 0.098 & \multirow{2}{*}{$11.77-12.06$} \\
\hline & $\Delta \lambda * *, \mathrm{~nm}$ & 141 & 143 & 142 & 141 & 140 & \\
\hline \multirow{2}{*}{$\mathrm{KOH}$} & $\mathrm{A}$ & 0.150 & 0.128 & 0.111 & 0.107 & 0.126 & \multirow{2}{*}{$11.84-12.23$} \\
\hline & $\Delta \lambda, \mathrm{nm}$ & 141 & 142 & 141 & 140 & 140 & \\
\hline \multirow{2}{*}{$\mathrm{Na}_{2} \mathrm{CO}_{3} * * *$} & $\mathrm{~A}$ & 0.341 & 0.360 & 0.378 & 0.457 & 0.549 & \multirow{2}{*}{$9.70-9.96$} \\
\hline & $\Delta \lambda, \mathrm{nm}$ & 42 & 39 & 40 & 47 & 37 & \\
\hline \multirow{2}{*}{$\mathrm{NaHCO}_{3} * * *$} & A & 0.217 & 0.247 & 0.193 & 0.157 & 0.169 & \multirow{2}{*}{$8.74-9.02$} \\
\hline & $\Delta \lambda, \mathrm{nm}$ & 74 & 74 & 75 & 71 & 72 & \\
\hline \multicolumn{8}{|c|}{$\begin{array}{ll}* & \text { Adding } 1 \mathrm{ml} \text { diazotised sulph } \\
* * & \Delta \lambda=\lambda_{\max } \mathrm{S}-\lambda_{\max } \mathrm{B} \\
& \text { where } \mathrm{S}=\text { The dye, } \mathrm{B}=\mathrm{Blank} \\
* * * & \text { Gives unstable azo-dye }\end{array}$} \\
\hline
\end{tabular}


The experimental data show that sodium carbonate and sodium bicarbonate give better sensitivity than sodium hydroxide and potassium hydroxide. But the later bases give better colour contrast and the azo-dye formed has good stability compared with weak bases, so that $1.5 \mathrm{ml}$ of $1 \mathrm{~N} \mathrm{NaOH}$ is recommended for the subsequent experiments.

Effect of diazotized sulphanilic acid reagent amount. The effect of the amount of the diazotized sulphanilic acid on the maximum absorbance of the azo-dye formed from different amounts of cephadroxil has been investigated. The results show that $4 \mathrm{ml}$ of diazotized sulphanilic acid $(50 \mathrm{mM})$ reagent solution gives the highest intensity with a correlation coefficient (r) of 0.998018 over a range of cephadroxil concentration 20-120 $\mu \mathrm{g} / 25 \mathrm{ml}$ (Table2), therefore $4 \mathrm{ml}$ is recommended for the subsequent experiments.

Table 2: The effect of diazotised sulphanilic acid amount on absorbance

\begin{tabular}{|c|c|c|c|c|c|c|c||}
\hline \hline $\begin{array}{c}\text { ml of Diazotised } \\
\text { sulphanilic acid } \\
\text { reagent solution } \\
(\mathbf{5 0 ~ m M )}\end{array}$ & \multicolumn{6}{|c|}{ Absorbance / $\boldsymbol{\mu g}$ of cephadroxil present } & \multirow{2}{*}{ r } \\
\cline { 2 - 9 } & $\mathbf{2 0}$ & $\mathbf{4 0}$ & $\mathbf{6 0}$ & $\mathbf{8 0}$ & $\mathbf{1 0 0}$ & $\mathbf{1 2 0}$ & \\
\hline \hline 1 & 0.04 & 0.067 & 0.083 & 0.113 & 0.158 & 0.187 & 0.99027 \\
\hline 2 & 0.043 & 0.072 & 0.103 & 0.125 & 0.167 & 0.196 & 0.997499 \\
\hline 3 & 0.048 & 0.079 & 0.117 & 0.145 & 0.179 & 0.200 & 0.997485 \\
\hline 4 & 0.051 & 0.088 & 0.132 & 0.159 & 0.205 & 0.250 & 0.998018 \\
\hline 5 & 0.055 & 0.081 & 0.124 & 0.151 & 0.192 & 0.256 & 0.989547 \\
\hline
\end{tabular}

\section{Effect of surfactant}

Table 3 shows that an addition of surfactants gives no useful effect. Therefore, it has been recommended to eliminate the use of surfactants in the subsequent experiments.

Table 3: Effect of surfactant.

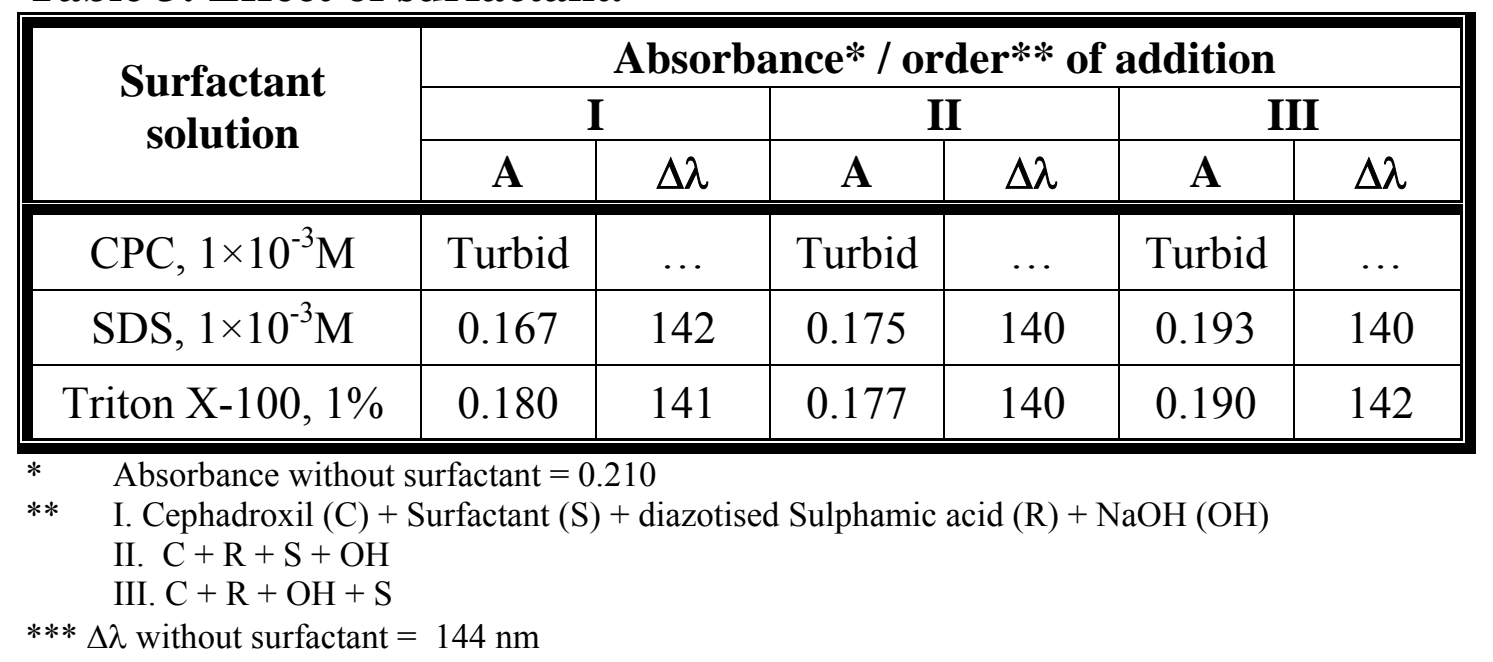




\section{Effect of time on colour development}

A study of the time effect on colour development showed that the colour formed practically within about one minute. The azo-dye formed from lower concentrations of cephadroxil gives good stability for at least 1 hour. At higher amounts of cephadroxil $(150 \mu \mathrm{g} / 25 \mathrm{ml})$, the resulting colo-ured azo-dye becomes unstable above 45 minutes (Table4).

Table 4: The effect of time and cephadroxil amount on absorbance

\begin{tabular}{|c||c|c|c|c|c|c|c|c|}
\hline \multirow{2}{*}{$\begin{array}{c}\mu \mathrm{g} \\
\text { Cephadroxil/ } \\
\text { 25ml }\end{array}$} & $\mathbf{0}$ & $\mathbf{1 0}$ & $\mathbf{2 0}$ & $\mathbf{3 0}$ & $\mathbf{4 0}$ & $\mathbf{4 5}$ & $\mathbf{5 0}$ & $\mathbf{6 0}$ \\
\cline { 2 - 10 } & 0.115 & 0.114 & 0.112 & 0.111 & 0.109 & 0.109 & 0.107 & 0.108 \\
\hline \hline 50 & 0.217 & 0.214 & 0.210 & 0.207 & 0.202 & 0.200 & 0.205 & 0.212 \\
\hline 100 & 0.25 & 0.323 & 0.320 & 0.315 & 0.312 & 0.318 & 0.337 & 0.388 \\
\hline 150 & 0.325 &
\end{tabular}

\section{Accuracy and precision.}

To check the accuracy and precision of the method, cephadroxil is determined at three different concentrations. The relative error $\%$ and relative standard deviation $\%$ results indicate the high accuracy and precision of the proposed method (Table 5).

Table 5: Accuracy and Precision of the method

\begin{tabular}{|c|c|c|}
\hline $\begin{array}{c}\text { Amount of } \\
\text { cephadroxil taken, } \\
\boldsymbol{\mu} \mathbf{g} \mathbf{2 5 m l}\end{array}$ & Relative error, \%* & $\begin{array}{c}\text { Relative standard } \\
\text { deviation, \%* }\end{array}$ \\
\hline 50 & -0.416 & \pm 2.408 \\
\hline 100 & +1.611 & \pm 2.249 \\
\hline 150 & +2.22 & \pm 1.686 \\
\hline
\end{tabular}

* Average of five determinations.

Nature of the dye. Job's and mole - ratio methods indicate that the dye has a composition of $1: 1$ cephadroxil to diazotized sulphanilic acid reagent Hence the dye may have the following structure (Fig3):

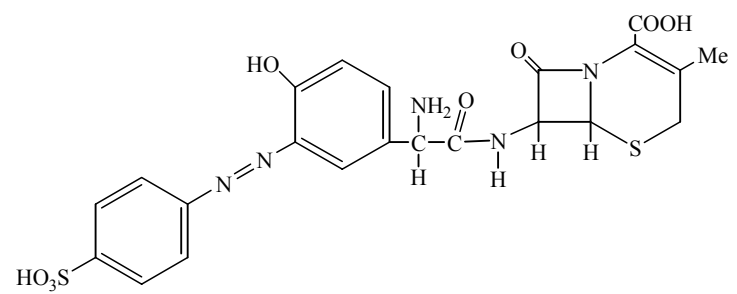

Fig. 3: The possible structure of the yellow azo-dye 
Diazotised Suhphanilic Acid Reagent for the Determination ...

\section{Interference}

The effect of some foreign compounds which often accompany pharmaceutical preparations are studied by adding three different amounts $(100,500$ and $1000 \mu \mathrm{g})$ to $100 \mu \mathrm{g}$ cephadroxil in a final volume of $25 \mathrm{ml}$ (Table 6 ).

Table 6: Effect of foreign compounds for assay of cephadroxil

\begin{tabular}{|c|c|c|c||}
\hline \multirow{2}{*}{$\begin{array}{c}\text { Foreign } \\
\text { compound }\end{array}$} & \multicolumn{3}{|c|}{$\begin{array}{c}\text { Recovery (\%) of } \mathbf{1 0 0} \boldsymbol{\mu} \text { g cephadroxil per } \boldsymbol{\mu g} \text { foreign } \\
\text { compound added }\end{array}$} \\
\cline { 2 - 4 } & $\mathbf{1 0 0}$ & $\mathbf{5 0 0}$ & $\mathbf{1 0 0 0}$ \\
\hline Glucose & 101.00 & 98.50 & 97.50 \\
\hline Glycerin & 102.10 & 100.52 & 101.05 \\
\hline Lactose & 98.50 & 99.50 & 97.00 \\
\hline Starch & 100.52 & 101.57 & 98.42 \\
\hline
\end{tabular}

The results in Table 6 indicate that the studied foreign compounds do not interfere in the determination of cephadroxil using the proposed method. An error not more than of $\pm 3 \%$ in the absorbance readings is considered tolerable from that of the cephadroxile alone.

\section{Analytical applications}

The proposed method is applied to determine cephadroxil in different pharmaceutical preparations. On applying proposed procedure, good recovery is obtained as shown in Table 7.

\section{Table7. Analytical applications}

\begin{tabular}{|c|c|c|c|}
\hline Pharmaceutical preparation & $\begin{array}{c}\mu \mathrm{g} \\
\text { Cephadroxil } \\
\text { present/25ml } \\
\end{array}$ & $\begin{array}{l}\mu \mathrm{g} \text { Cephadroxil } \\
\text { measured/25ml }\end{array}$ & $\begin{array}{c}\text { Recovery, } \\
\%\end{array}$ \\
\hline \multirow{3}{*}{$\begin{array}{c}\text { Cephadroxil tablets } \\
\text { (500mg/tablet) Ajanta } \\
\text { Pharma Limited (India) }\end{array}$} & 100 & 99.02 & 99.02 \\
\hline & 150 & 152.40 & 101.60 \\
\hline & 200 & 201.94 & 100.97 \\
\hline \multirow{3}{*}{$\begin{array}{l}\text { Cephadroxil capsules } \\
\text { (500mg/capsule) Bristol } \\
\text { Myerssquibb (Egypt) }\end{array}$} & 100 & 103.60 & 103.60 \\
\hline & 150 & 152.53 & 101.69 \\
\hline & 200 & 204.76 & 102.38 \\
\hline \multirow{3}{*}{$\begin{array}{l}\text { Cephadroxil oral suspenstion } \\
\text { syrup (250mg/5ml) } \\
\text { pharmaceutical (India) }\end{array}$} & 100 & 98.00 & 98.00 \\
\hline & 150 & 148.99 & 99.33 \\
\hline & 200 & 197.50 & 98.75 \\
\hline
\end{tabular}

* Average of three determinations. 


\section{Evaluation of the proposed method}

Due to the difficulties of using the standard method for determination of cephadroxil in its pharmaceutical preparations [18], instead we used standard addition method in order to prove that the proposed method is applied to the determination of cephadroxil without interferences (Table 8).

Table 8. The results of standard addition method

\begin{tabular}{|c|c|c|c|}
\hline Pharmaceutical preparation & $\begin{array}{c}\mu \mathrm{\mu} \\
\text { cephadroxil } \\
\text { present/25ml }\end{array}$ & $\begin{array}{c}\mu \mathrm{g} \text { cephadroxil } \\
\text { measured/25ml }\end{array}$ & $\begin{array}{c}\text { Recovery, } \\
\text { \% }\end{array}$ \\
\hline Cephadroxil tablets( 500mg/tablet) & 50 & 51.5 & 103.0 \\
\cline { 2 - 4 } Ajanta Pharma Limited (India) & 100 & 100.5 & 100.5 \\
\hline $\begin{array}{c}\text { Cephadroxil capsules } \\
\text { (500mg/capsule) Bristol- } \\
\text { Myerssquibb (Egypt) }\end{array}$ & 50 & 52.0 & 104.0 \\
\cline { 2 - 4 } & 100 & 100.0 & 100.0 \\
\hline $\begin{array}{c}\text { Cephadroxil oral suspenstion } \\
\text { syrup (250mg/5ml) } \\
\text { pharmaceutical (India) }\end{array}$ & 50 & 50.5 & 101.0 \\
\cline { 2 - 4 } & 100 & 99.0 & 99.0 \\
\hline
\end{tabular}

* Average of three determinations

The results in Table 8 are in agreement with certified values of pharmaceutical preparations and with the standard addition procedure.

\section{Comparison of the methods}

The results of comparison between the analytical variables of the present method with other spectrophotometric methods show that the present method is sensitive for the determination of cephadroxil and has a wider application part(Table 9).

Table 9. Comparison of the methods

\begin{tabular}{||l|c|c|c||}
\hline \multicolumn{1}{|c|}{$\begin{array}{c}\text { Analytical } \\
\text { parameters }\end{array}$} & $\begin{array}{c}\text { Present } \\
\text { method }\end{array}$ & $\begin{array}{c}\text { Literature } \\
\text { method }^{\mathbf{9})}\end{array}$ & $\begin{array}{c}\text { Literature } \\
\text { method }^{\mathbf{1 0 0}}\end{array}$ \\
\hline $\mathrm{pH}$ & 11.82 & $\ldots$ & $\ldots$ \\
\hline Temperature $\left(\mathrm{C}^{\circ}\right)$ & $\begin{array}{c}\text { Room } \\
\text { temperature }\end{array}$ & $\begin{array}{c}\text { Room } \\
\text { temperature }\end{array}$ & Room temperature \\
\hline$\lambda \max (\mathrm{nm})$ & 445 & 479 & 500 \\
\hline Medium of reaction & Aqueous & Aqueous & Aqueous \\
Type of reaction & Diazo coupling & $\begin{array}{c}\text { Diazo } \\
\text { coupling }\end{array}$ & Oxidative coupling \\
\hline Reagent & $\begin{array}{c}\text { Diazotised } \\
\text { sulphanilic } \\
\text { acid }\end{array}$ & $\begin{array}{c}\text { Diazotised } \\
\text {-nitroaniline }\end{array}$ & $\begin{array}{c}\text { 4-Amino- antipyrine } \\
\text { with potassium } \\
\text { hexacyano- pherrate }\end{array}$ \\
\hline
\end{tabular}




\begin{tabular}{|c|c|c|c|}
\hline $\begin{array}{l}\text { Beer's law range } \\
\text { (ppm) } \\
\text { Molar absorptivity } \\
\left(1 . \mathrm{mol}^{-1} . \mathrm{cm}^{-1}\right)\end{array}$ & $\begin{array}{c}0.4-9.6 \\
1.73 \times 10^{4}\end{array}$ & $\begin{array}{c}0.4-8 \\
2.22 \times 10^{4}\end{array}$ & $\begin{array}{c}1-28 \\
1.30 \times 10^{4}\end{array}$ \\
\hline Colour of the dye & Yellow & Orange & Red \\
\hline Nature of the dye & $1: 1$ & $1: 1$ & $1: 1$ \\
\hline $\begin{array}{l}\text { Application of the } \\
\text { method }\end{array}$ & $\begin{array}{l}\text { Has been } \\
\text { applied to the } \\
\text { assay of } \\
\text { cephadroxil in } \\
\text { pharmaceutical } \\
\text { preparations } \\
\text { (tablets, } \\
\text { capsules and } \\
\text { suspensions) }\end{array}$ & $\begin{array}{l}\text { Has been } \\
\text { applied to the } \\
\text { assay of } \\
\text { cephadroxil in } \\
\text { pharmaceutical } \\
\text { preparations } \\
\text { (tablets and } \\
\text { suspensions) }\end{array}$ & $\begin{array}{l}\text { Has been applied } \\
\text { to the assay of } \\
\text { cephadroxil in } \\
\text { pharmaceutical } \\
\text { preparations } \\
\text { (capsules and } \\
\text { suspensions) }\end{array}$ \\
\hline
\end{tabular}

\section{Conclusion}

The proposed method is simple and sensitive, do not need any pretreatment of cephadroxil or extraction of the dye formed, has good accuracy and precision and has been successfully applied to the determination of cephadroxil in various pharmaceutical preparations.

\section{References}

1. http://www.Drugs.com.cephadroxil drug information.

2. Ting S., J. Assoc. Off. Anal. Chem., 71 (6), 1123-1130(1988).

3. Manna L. and Valvo L. J. Chromatogr., 60 (11-12), 645-649 (2004).

4. Awni F. IKhalil H. S. and Esmadi F., Anal. Lett., 32 (15), 29772988 (1999).

5. Thongpoon C. Liawruangrath B. Liawrungrath S. Wheatley R. and Townshend A., J. Pharm. Biomed. Anal., 42 (2), 277-282 (2006).

6. Yang J. Zhou X. Cao Q. and Dong J., Anal. Lett., 31 (6), 10471060 (1998). 
7. El-Walily A. F. Gazy A. A. Belal S. F. and Khamis E. F. J. Pharm. Biomed. Anal., 20 (4), 643-653 (1999).

8. El-Ashry S. M., El-Kerdawy M. M. and Wassef D. R. E., Microkhim. Acta 135 (3-4), 191-196 (2000).

9. Othman N. S. Mansour S. and Al-Shaheen Sh., Tikrit J. Pure Sci., 11 (2), 201-203 (2006).

10. Aly F. A., Walash M. I. and Belal F., Anal. Lett., 27 (14), 26772687 (1994).

11. Sastry C. S. P., Rao K. R. and Prasad D. S., Mikrochim. Acta, 126 (1-2), 167-172 (1997).

12. Badawy S. S. Abdeel-Gawad F.M. and Ibrahim M. M. Anal. Lett., 26 (3), 487-497. (1993).

13. Prasad M. V. Nagaraju R. and. Narayan T. V., Indian J. Pharm. Sci., 66 (3), 341-342 (2004).

14. Issopoulos. P. B., Analyst, 114 (2), 237-239 (1989).

15. Salem H. and Saleh G. A., J. Pharm. Biomed. Anal., 28 (6), 1205213 (2002).

16. Salem H., Anal. Chim. Acta, 515(2), 333-341(2004).

17. Ahmad A. K., Hessan Y. I. and Bashir W. A., Analyst, , 111 (2), 243-244 (1986).

18. British Pharmacopeia on CD-ROM", 3rd Edn., System Simulation Ltd, the stationary office, London, (2000). 